\title{
Pyogranulomatous dermatitis and panniculitis due to Nocardia nova in a cat
}

\author{
Dermatite e paniculite piogranulomatosas causadas por Nocardia nova em um gato
}

\author{
Guilherme Reis Blume ${ }^{\mathrm{I}}$ Christine Souza Martins ${ }^{\mathrm{I}}$ Letícia Beatriz Matter ${ }^{\mathrm{II}}$ \\ Agueda Palmira Castagna de Vargas ${ }^{I I}$ Letícia Batelli de Oliveira ${ }^{\mathrm{I}}$ \\ Janildo Ludolf Reis Junior ${ }^{I}$ Fabiano José Ferreira de Sant'Ana ${ }^{I^{*}}$
}

- NOTE -

\section{ABSTRACT}

This report describes the clinical, pathological and microbiological findings of an uncommon infection in a cat by Nocardia nova. A 3-year-old male domestic short hair cat with an ulcerated and exudative cutaneous wound was presented for clinical examination. Samples were collected for histopathology and bacteriology diagnosis. Microscopically, the lesion was diagnosed as pyogranulomatous dermatitis and panniculitis with large and irregular colonies of branching filamentous bacterium. Skin bacteriological culture showed gram-positive rods and partially acid-fast branching filaments by gram and kinyoun staining, respectively. The identity of Nocardia nova was confirmed by $16 S \mathrm{rDNA}$ sequencing and phylogenetic analysis. This is the first case of pyogranulomatous dermatitis and panniculitis in a cat caused by Nocardia nova reported in Brazil.

Key words: cat, dermatopathology, nocardiosis.

\section{RESUMO}

Este relato descreve os achados clínicos, patológicos e microbiológicos de uma infecção incomum por Nocardia nova em um gato. Um gato macho, sem raça definida, de 3 anos de idade, apresentou ferida cutânea exsudativa e ulcerada. Amostras da lesão foram coletadas para histopatologia e bacteriologia. Histologicamente, a lesão consistiu de dermatite e paniculite piogranulomatosas associadas a colônias grandes e irregulares de bactérias filamentosas e ramificadas. $O$ cultivo bacteriológico revelou bacilos filamentosos, gram-positivos, parcialmente ácido resistentes, visualizados pelas colorações de Gram e Kinyoun, respectivamente. A identificação da Nocardia nova foi confirmada pelo sequenciamento $16 \mathrm{~S}$ rDNA e análise filogenética. Este é o primeiro caso de paniculite e dermatite piogranulomatosas em um gato causado por Nocardia nova registrado no Brasil.

Palavras-chave: gato, dermatopatologia, nocardiose
Nocardia spp. are aerobic, grampositive, partial acid-fast, filamentous bacteria and ubiquitous environmental saprophytes responsible for granulomatous or suppurative infections (RIBEIRO et al., 2008). The bacteria belong to the order Actinomycetales, family Nocardiacea and the main species that affect domestic animals are $N$. asteroides, $N$. brasiliensis, $N$. otitidiscaviarum, and N. nova (HARADA et al., 2009). $\boldsymbol{N}$. brasiliensis is the most common species affecting humans in tropical countries, such as central and south America (SYKES, 2012), where as $\boldsymbol{N}$. otitidiscaviarum was considered the specie more isolated in dogs from Brazil (RIBEIRO et al., 2008) and has been occasionally reported in a cat from Spain (LUGUE et al., 2002).

Nocardiosis can affect many domestic animals, but is uncommon in cats (RIBEIRO et al., 2008). Immunosuppression associated to multidrug therapy or concurrent infections is an important predisposing factor to the development of the disease in animals and humans (RIBEIRO et al., 2002). Clinically, nocardios can present as systemic, pulmonary, nervous, and cutaneous form (BEAMAN \& BEAMAN, 1994). Cutaneous nocardiosis is the most common form in cats and causes localized nodules, cellulitis, and abscesses (SYKES, 2012).

The route of infection and transmission occurs by inhalation of aerosols containing the agent, ingestion or direct contact with contaminated environment

\footnotetext{
'Laboratório de Patologia Veterinária (LPV), Universidade de Brasília (UnB), Campus Universitário Darcy Ribeiro, 70910-900, Brasília, DF, Brasil. E-mail: santanafjf@yahoo.com. "Corresponding author.

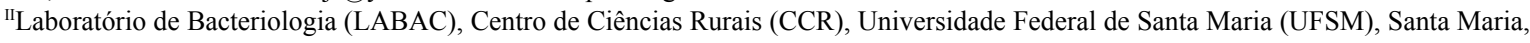
RS, Brasil. 
(SYKES, 2012). Diagnosis is made by history, clinical signs and hematological, microbiological, anatomopathological, and molecular tests (RIBEIRO et al., 2002). This study aims to report the clinical, pathological and microbiological findings of a case of feline pyogranulomatous dermatitis and panniculitis associated to Nocardia nova. This specie has not been yet associated to nocardiosis in cats in Brazil.

A 3-year-old, spayed, male, short hair cat presented history of a progressive skin lesion in the thoracic region for about six months. Clinical examination showed multiple channels connecting the ulcerated skin with the subcutis and extended from the right scapula to the right thorax that drained serosanguineous secretion (Figure 1A). Hematologic results revealed neutrophilic leukocytosis with leftshift and toxic neutrophils. Serological tests for feline immunodeficiency (FIV) and feline leukemia virus (FeLV) were negative.

The animal was treated with antibiotics including enrofloxacin $\left(5 \mathrm{mg} \mathrm{kg}{ }^{-1}\right.$, Baytril ${ }^{\circledR}$ Flavour, Bayer, São Paulo/SP, Brazil), amoxicillin associated with potassium clavulanate $\left(20 \mathrm{mg} \mathrm{kg}^{-1}\right.$, Synulox ${ }^{\circledR}$, Zoetis, Campinas/SP, Brazil) and ampicillin (25mg kg-1 Ampicilina Veterinária Oral ${ }^{\circledR}$, Vetnil,
Louveira/SP, Brazil) but there was no clinical improvement. The animal was also treated with methylprednisolone acetate $\left(20 \mathrm{mg} \mathrm{kg}^{-1}\right.$, Depo$\mathrm{Medrol}^{\circledR}$, Pfizer, Guarulhos/SP, Brazil) by another veterinarian during a trip. After this last treatment, the cutaneous lesion increased considerably.

Due to worsening of the skin lesions, surgical excision was performed. Samples were collected for bacteriological and molecular diagnosis. Additional samples was fixed in buffered $10 \%$ formalin, routinely processed for histopathology, and stained by hematoxylin and eosin, Brown Y Brenn (Gram), and modified Fite-Faraco.

Microscopically, expending, infiltrating and distorting the dermis, panniculum and adjacent skeletal muscle, there were focally extensive areas with multiple pyogranulomas containing large, central, and irregular colonies of branching filamentous bacteria (Figure 1C). The organism was Brown Y Brenn- and Fite-Faraco positive (Figure 1D). In addition, adjacent to the bacteria there were numerous degenerate and intact neutrophils with an outer layer of epithelioid macrophages and fewer lymphocytes, plasma cells, and rare multinucleated giant cells. Moderate proliferation of loose fibrovascular stroma and edema

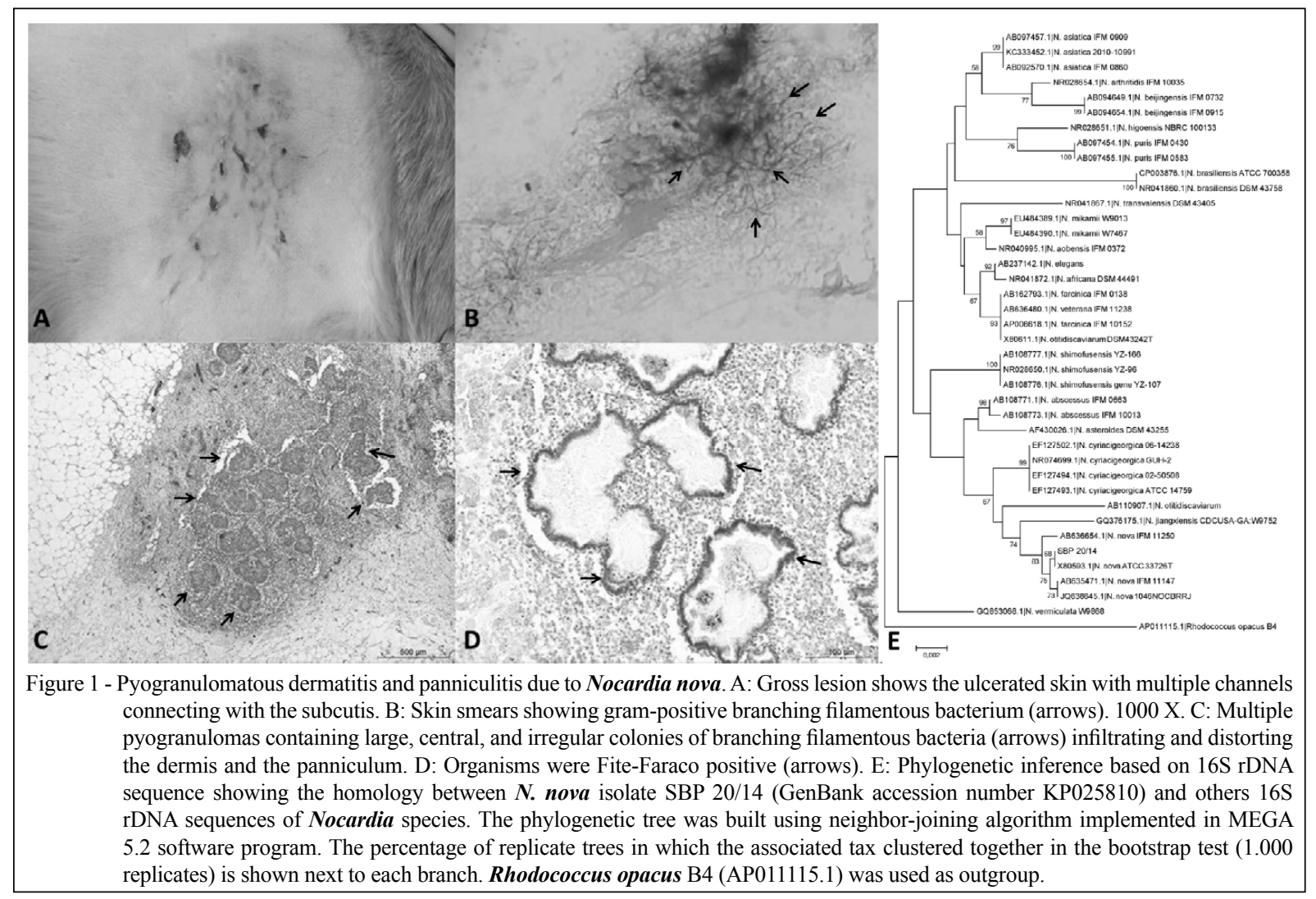

Ciência Rural, v.45, n.11, nov, 2015. 
around pyogranulomas were observed. Multifocally, there are multiple anastomosing channels filled with necrotic debris and inflammatory cells. Often, these channels were interconnected with skin ulcers.

Gram staining of the skin smear showed gram-positive branching filamentous bacterium (Figure 1B). Colonies were isolated from the skin on blood agar and brain heart infusion agar after 3 days at $37^{\circ} \mathrm{C}$ of incubation. Bacteria isolation was possible only from the removed tissue. All colonies had the same aspect and resembled Nocardia colonies. Due to the rapid and reliable result, molecular diagnosis by $16 \mathrm{~S}$ rDNA was performed instead the biochemical tests. DNA from colonies (SBP 20/14) was extracted by lysis with cetyltrimethylammonium bromide (CTAB) (SAMBROOK \& RUSSELL, 2001). Molecular diagnosis was obtained by analyzing the partial sequence ( $\sim 1400$ base pairs) of the16S rRNA gene amplified with universal primers (FREDRICKS \& RELMAN, 1998). PCR product was sequenced by ACT Gene Análises Moleculares (Centro de Biotecnologia, UFRGS, Brazil) using the automatic sequencer ABI-PRISM 3100 genetic analyzer (Applied Biosystems). Chromatograms obtained by sequencing were analyzed, and consensus sequences were assembled using 4 sStaden package programs (STADEN et al., 2000).

In order to compare the consensus sequence $(\sim 1400 \mathrm{bp})$ with other sequences available on GenBank database <http://www.ncbi.nlm.nih. gov $>$ BLASTN tool was performed. The closest relative $16 \mathrm{~S}$ rDNA sequence was used for the bacterial identification. The sample showed $100 \%$ homology to $N$. nova (Evalue 0.0).

In addition, phylogenetic inference of the consensus with other GenBank sequences was preceded. The phylogenetic inference showed the strong homology of the isolate with others N. nova strains and the relationship with others species available in Genbank dataset (Figure 1E). Furthermore, the cat presented clinical improvement and there was no indication of recurrence of skin lesions at one year after the surgical removal.

Nocardia spp. has a worldwide distribution, and is considered an opportunistic pathogen. Bacteria are facultative intracellular organisms which contain important virulence factors, such as resistance to phagocytosis and complex cell wall lipids (BEAMAN \& BEAMAN, 1994). Nocardiosis affects especially dogs and cats, but can infect other species, such as cattle, horses, pigs, poultry, and humans (RIBEIRO et al., 2008). The main lesions observed in companion animals include skin lesions, pyothorax and pneumonia (MALIK et al., 2006). In the present case, the lesions were restricted to skin and adjacent tissues and there were no clinical signs compatible with pulmonary and disseminated involvement.

In a study of 53 cases of canine nocardiosis from California (USA), the disease was diagnosed more frequently in male and young animals (BEAMAN \& SUGAR, 1983), as noted in the current report. Some authors cite higher prevalence of nocardiosis in male cats because they are often roaming or fighting and the lesions are associated to scratches or bite wounds (SYKES, 2012). Usually, animals with cutaneous nocardiosis can present transcutaneous transmission and contagion by penetration of the agent into the skin, causing cellulitis, pustules, pyoderma, or abscesses (MALIK et al., 2006). In the current report, it was not possible to determine the precise route and source of infection.

Renal transplantation, retroviral infection, or glucocorticoid treatment are considered important predisposing factors for the disease in cats (SYKES, 2012). However, these were not the cases. Serological tests for feline immunodeficiency (FIV) and feline leukemia virus (FeLV) were negative. Glucocorticoid was used as treatment but it was before the conclusion of the nocardiosis diagnosis, what increased significantly the cutaneous lesion.

Hematologic findings were very similar to a previous study that described also monocytosis and hyperglobulinemia in a cutaneous nocardiosis in a dog (GOLYNSKKY et al., 2006). In the current case, the histopathology and mainly the molecular analysis were paramount for the diagnosis of pyogranulomatous dermatitis and panniculitis due to $N$. nova. Histopathological lesions were similar to those visualized in other previously reported cases (LUGUE et al., 2002; MALIK et al., 2006). Actinomyces spp., Streptomyces spp., Mycobacterium spp., Rhodococcus spp., Corynebacterium spp., Dermatophilus congolensis and saprophytic fungi should be considered as differentials for cutaneous nocardiosis (RIBEIRO et al., 2002; MALIK et al., 2006).

By indication of the owner and due to prolonged time of skin infection, the surgical treatment with removal of the affected tissues was performed. This treatment was considered effective and curative, because there was no recurrence of the lesion after 1 year of procedure.

Further epidemiologic, pathological and molecular studies are necessary to determine the real prevalence, pathogenesis and specific route of the infection by $\boldsymbol{N}$. nova in cats. To the author's knowledge, this is the first feline case of 
pyogranulomatous dermatitis and panniculitis due to $N$. nova reported in Brazil.

\section{ETHICS COMITTE AND BIOSECURITY}

This report met with an animal runs in the routine of the University Veterinary Hospital (UnB) and was not part of any project, with only one case report.

\section{REFERENCES}

BEAMAN, B.L.; SUGAR, A.M. Nocardia is naturally acquired and experimental infections in animals. Journal of Hygiene, v.91, p.393-419, 1983

BEAMAN, B.L.; BEAMAN, L. Nocardia species: host-parasite relationships. Clinical Microbiology Reviews, v.7, p.213-264, 1994. Available from: <http://cmr.asm.org/content/7/2/213.full. pdf + html $>$. Accessed: May 12, 2015. doi: 10.1128/CMR.7.2.213.

FREDRICKS, D.N.; RELMAN D.A. Improved amplification of microbial DNA from blood cultures by removal of the PCR inhibitor sodium polyanetholesulfonate. Journal of Clinical Microbiology, v.36, p.2810-2816, 1998. Available from: <http://jcm.asm.org/ content/36/10/2810.full.pdf + html $>$. Accessed: May 12, 2015.

GOLYŃSKY, M. et al. Cutaneous Nocardiosis in a dog - Clinical case presentation. Bulletin of the Veterinary Institute in Pulawy, v.50, p.47-50, 2006
HARADA, H. et al. Cutaneous nocardiosis in a cat. Journal of Veterinary Medical Science, v.71, p.785-787, 2009. Available from: <https://www.jstage.jst.go.jp/article/jvms/71/6/71_6_785/_ pdf $>$. Accessed: May 12, 2015. doi: 10.1292/jvms.71.785.

LUGUE, I. et al. Nocardia otitidiscaviarum infection in a cat. Veterinary Record, v.151, p.488, 2002.

MALIK, R. et al. Nocardia infections in cats: a retrospective multiinstitutional study of 17 cases. Australian Veterinary Journal, v.84, p.235-245, 2006. Available from: <http://onlinelibrary.wiley. com/doi/10.1111/j.1751-0813.2006.00004.x/epdf >. Accessed: May 12, 2015. doi: 10.1111/j.1751-0813.2006.00004.x.

RIBEIRO, M.G. et al. Nocardiose cutânea associada à cinomose em cães. Relato de dez casos. Clínica Veterinária, v.39, p.34-42, 2002.

RIBEIRO, M.G. et al. Nocardiosis: an overview and additional report of 28 cases in cattle and dogs. Revista do Instituto de Medicina Tropical, v.50, p.177-185, 2008. Available from: $<$ http://www.scielo.br/pdf/rimtsp/v50n3/7407.pdf>. Accessed: May 12, 2015. doi: 10.1590/S0036-46652008005000004.

SAMBROOK, J.; RUSSELL, D.W. Molecular cloning. New York: CSHL, 2001. 2344p.

STADEN, R. et al. The staden package, 1998. Methods in Molecular Biology, v.132, p.115-130, 2000.

SYKES, J.E. Actinomycosis and nocardiosis. In: GREENE, C.E. In: Infectious diseases of the dog and cat. 4.ed. St. Louis: Elsevier, 2012. p.451-461. 